\title{
Nowe prace nad wykorzystaniem napawania łukowego MIG/MAG do drukowania 3D
}

\author{
New work on the use of MIG/MAG arc welding for 3D printing
}

\section{Streszczenie}

Problematyka wielowarstwowego napawania łukowego metodami MIG/MAG w celu tworzenia obiektów 3D jest głównym obszarem badawczym spawalniczego koła naukowego "Joint", zrzeszającego studentów Politechniki Warszawskiej zgromadzonych wokół Zakładu Inżynierii Spajania. Na obecnym etapie uzyskano dużą powtarzalność przy zrobotyzowanym tworzeniu obiektów walcowych uzyskiwanych z różnych stali. W artykule przedstawiono najnowsze osiągnięcia oraz określono perspektywy dalszych rozwoju.

Słowa kluczowe: techniki przyrostowe; drukowanie 3D; robotyzacja; napawanie

\section{Abstract}

The issues of multilayer arc welding with MIG/MAG methods to create $3 \mathrm{D}$ objects is the main research area of the "Joint" welding scientific club, which associates students of the Warsaw University of Technology gathered around the Welding Engineering Department. At the current stage, high repeatability was obtained with robotic creation of cylindrical objects obtained from various steels. The article presents the latest achievements and defined prospects for further development.

Keywords: additive manufacturing; 3D printing; robotization; pad welding

\section{Wprowadzenie}

Terminem drukowania bądź modelowania 3D określa się zbiór metod precyzyjnego i powtarzalnego wytwarzania elementów w oparciu o techniki przyrostowe [4,5]. Polegają one na wielokrotnym nakładaniu warstw w celu osiągnięcia obiektu o założonym kształcie i wymiarach. Techniki przyrostowe charakteryzują się zazwyczaj mniejszą dokładnością i wytrzymałością w stosunku do wyrobów wytwarzanych w oparciu o techniki tradycyjne, nie wymagają jednak specyficznego dla tych technik oprzyrządowania technologicznego oraz narzędzi.

Można wskazać kilka głównych obszarów zastosowania przyrostowego druku 3D [4]:

1. Szybkie modelowanie (ang. Rapid Modeling) - szybkie wytwarzanie modeli, zwykle mniej dokładnych i wytrzymałych w porównaniu do uzyskanych technikami tradycyjnymi.

2. Szybkie prototypowanie (ang. Rapid Prototyping) - wytwarzanie prototypów w możliwie najlepszy sposób naśladujących rzeczywisty obiekt.

3. Szybkie wytwarzanie (ang. Rapid Manufacturing) - wytwarzanie w pełni funkcjonalnych obiektów, np. części maszyn.

4. Szybkie wytwarzanie narzędzi (ang. Rapid Tooling) - wytwarzanie w pełni funkcjonalnych narzędzi, za pomocą których można wykonać serię nowych produktów.

Techniki modelowania 3D obejmują kilkadziesiąt metod formowania obiektów bezpośrednio z ciała stałego, a także z proszku, fazy ciekłej i gazowej. Wśród nich wskazać można także metody o charakterze spawalniczym, opartych głównie na selektywnym spiekaniu lub stapianiu metalowych proszków przy użyciu wiązki elektronowej lub lasera [4]. Oferują one zwykle wysokiej jakości modele, bazując jednak na niezwykle kosztownym sprzęcie i materiałach.

Wybór napawania łukowego MIG/MAG (ang. Metal Inert Gas/Metal Active Gas) do tworzenia obiektów 3D nie był przypadkowy. W ten sposób od dawna realizowana jest modyfikacja i naprawa uszkodzonych lub zużytych powierzchni części maszyn. Metalurgiczne związanie warstwy napawanej z podłożem zapewnia wysokie walory użytkowe powłok. W przypadku niektórych napraw konieczne jest precyzyjne nałożenie na uszkodzone powierzchnie wielu warstw napoin, także w sposób zrobotyzowany, aż do uzyskania nominalnej geometrii $[1 \div 3]$.

Pomimo tego, napawanie łukowe MIG/MAG nie jest powszechnie kojarzone z technikami przyrostowego drukowania 3D. Dopiero w ciągu kilku ostatnich lat obserwuje się wzmożone zainteresowanie tą metodą $[5,6,8]$.

Wykorzystaniu napawania łukowego MIG/MAG do drukowania 3D sprzyja przede wszystkim [7,9]:

- dostępność i relatywnie niski koszt maszyn oraz materiatów dodatkowych;

- pojawienie się nowych odmian niskoenergetycznych, wprowadzających mniejszą ilość ciepła przy często znacznie

Dr inż. Paweł Cegielski, Mateusz Ostrysz, Wojciech Łacisz, Marcin Panas, Patryk Kowalski - Politechnika Warszawska.

Autor korespondencyjny/Corresponding author. pcegiels@wip.pw.edu.pl 
lepszej kontroli i stabilności procesu, np. CMT (ang. Cold Metal Transfer) firmy Fronius;

- łatwość sterowania procesem, analogicznie do spawania MIG/MAG, przede wszystkim podczas korzystania z synergicznych źródeł inwertorowych;

- łatwość robotyzacji (przez analogię do spawania MIG/ MAG), kluczowe z uwagi na długotrwałe wytwarzanie złożonych form przestrzennych;

- powszechność stosowania napawania łukowego do miejscowych napraw na powierzchniach części maszyn.

W projektach koła naukowego wykorzystano jedną z najbardziej zaawansowanych odmian metody MIG/MAG - niskoenergetyczną CMT. Polega ona na spawaniu z impulsowym podawaniem topliwej elektrody, gdzie przenoszenie metalu odbywa się poprzez siły napięcia powierzchniowego wspomagane wycofywaniem się drutu z ciekłego jeziorka. W metodzie zredukowano ilość ciepła wprowadzanego do złącza przy równoczesnym zapewnieniu wysokiej kontroli i stabilności procesu.

\section{Stanowisko i warunki modelowania}

Podstawowy system spawalniczy wykorzystywany przez zespół do badań nad zastosowaniem napawania łukowego MIG/MAG do drukowania 3D oparty jest na zmodernizowanym robocie przemysłowym IRp-6 (ZAP Robotyka), zsynchronizowanym pozycjonerze obrotowym (zewnętrzna oś robota) oraz spawalniczym źródle TPS 2700 CMT firmy Fronius (rys. 1). Komunikacja źródło - robot realizowana jest poprzez interfejs cyfrowy ROB 3000. Sprzęt wspomagający to m.in.: panel do sterowania i kontroli źródła RCU 5000i (Fronius) oraz pirometry i mierniki z termoparami do pomiaru i rejestracji temperatury.

Modele tworzone są na powierzchniach płytek startowych, początkowo wykonanych ze stali konstrukcyjnej S235, a obecnie także nierdzewnej 304, zwykle o wymiarach $50 \div 150 \times 100 \mathrm{~mm}$ i grubości $2,5 \div 4,0 \mathrm{~mm}$, metalicznie czystych i odtłuszczonych. Napawanie odbywa się przy wykorzystaniu drutu elektrodowego i gazu osłonowego odpowiadającego płytkom startowym. Dla stali S235 stosowany jest drut G3Si1 (ESAB) o średnicy $0,8 \mathrm{~mm}$ oraz gaz osłonowy M21 (80\% Ar i 20\% $\mathrm{CO}_{2}$ ). Dla stali nierdzewnych - druty ER 308 i ER 316LSi (ESAB) o średnicy $0,8 \mathrm{~mm}$ oraz mieszanina argonu z $2 \%$ domieszką $\mathrm{O}_{2}$.

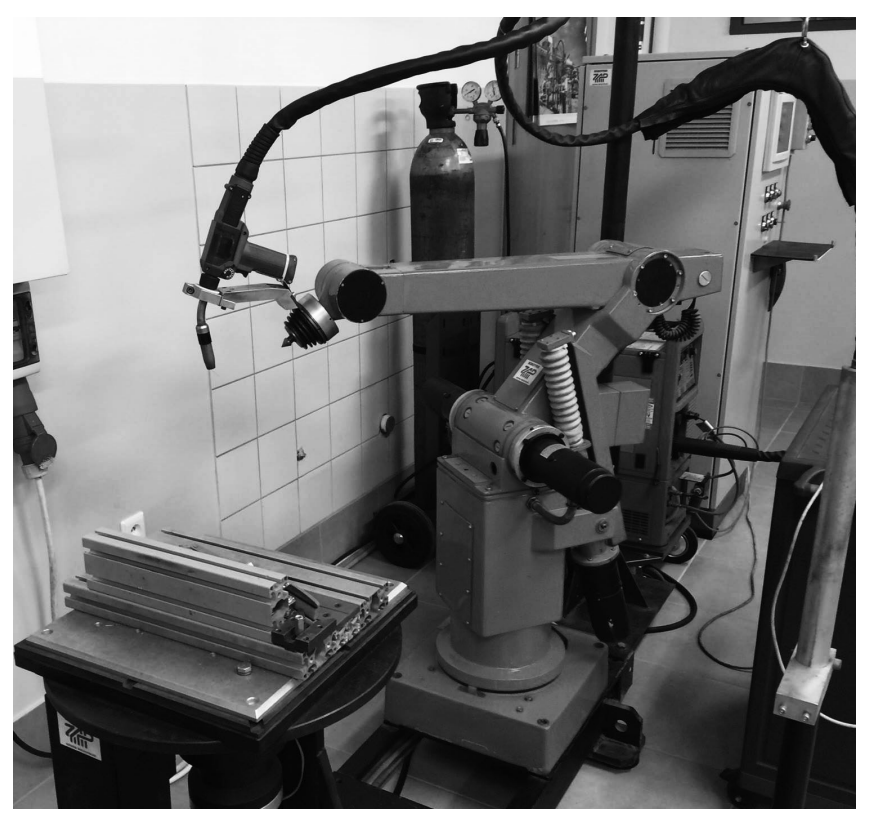

Rys. 1. Widok ogólny wykorzystywanego stanowiska z robotem IRp-6 i źródłem CMT

Fig. 1. General view of the used station with IRp- 6 robot and CMT source

\section{Nowe projekty}

Początkowe prace badawcze zespołu wiązały siętworzeniem najprostszych form geometrycznych - cienkościennych (jednowarstwowych) ścian (płaskich i narożnych) oraz walców. Przy ich pomocy ustalano wyjściowe parametry technologiczne oraz ogólne zasady programowania robota. Napawano w pozycjach podolnej i naściennej oraz w położeniach pośrednich. Modele walcowe uzyskiwano podczas równoczesnego obrotu stołu pozycjonera i korekcyjnego podnoszenia uchwytu elektrodowego. Modele płaskie tylko poprzez wielokierunkowy ruch robota. Jednym z ciekawszych projektów było wytworzenie piasty, którą następnie poddano częściowej obróbce wykańczającej poprzez toczenie $[7,8,10]$.

W toku najnowszych badań i eksperymentów udało się uzyskać powtarzalne "wydruki” cienkościennych (jednowarstwowych) ścian, a przede wszystkim obiektów walcowych o znacznej wysokości i większym niż poprzednio skomplikowaniu kształtu, głównie przy wykorzystaniu drutów nierdzewnych ER 308 i ER 316LSi. Początkowo, materiał nierdzewny sprawiał szereg trudności podczas wielowarstwowego, precyzyjnego napawania. Nawet niewielka zmiana parametrów, w tym ustawienia osi elektrody, powodowała niestabilność oraz duże zmiany efektu napawania.

Po wypracowaniu właściwych parametrów napawania drutami ER 308 i ER 316LSi, w tym zasad programowania ruchu elektrody, możliwe stało się zrobotyzowane wytwarzanie efektownych, cienkościennych obiektów o znacznej wysokości (rys. $2 \div 4$ ). W projekcie „kieliszek” (rys. 4) największe

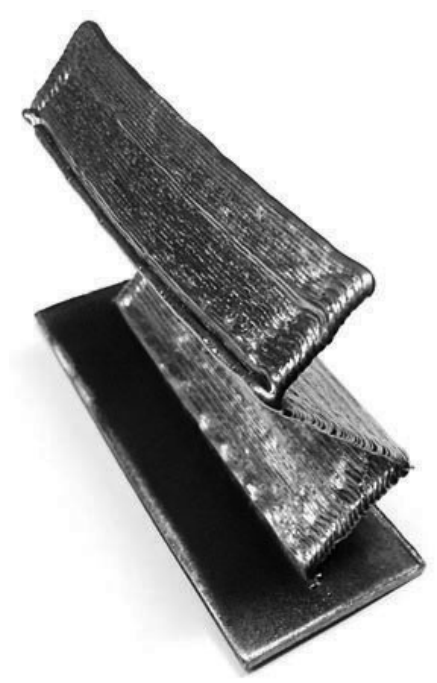

Rys. 2. Wielokierunkowa ściana złożona z 140 warstw z drutu ER 316LSi Fig. 2. A multidirectional wall composed of 140 layers of ER $316 \mathrm{LSi}$ wire

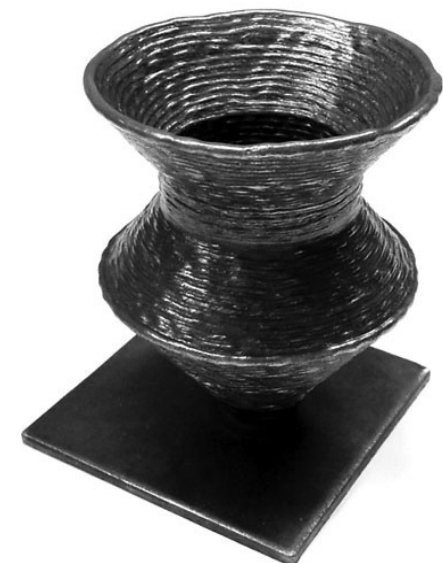

Rys. 3. Wazon o wysokości ok. $120 \mathrm{~mm}$ i średnicy zewnętrznej $100 \mathrm{~mm}$ wytworzony z drutu ER 316LSi [9]

Fig. 3. Vase with a height of approx. $120 \mathrm{~mm}$ and an external diameter of $100 \mathrm{~mm}$ made of ER 316LSi wire [9] 
wyzwanie stanowiła ustawiona na stożkowej podstawie nóżka o średnicy ok. $6 \mathrm{~mm}$, na której wybudowano naczynie. Należy zaznaczyć, że zaprezentowane modele są w pełni powtarzalne.

Ciekawe efekty uzyskano podczas prób wydruków częściowych, bazujących na elementach gotowych, wytworzonych technikami konwencjonalnymi. Na rysunku 5 pokazano model podajnika ślimakowego uzyskanego $\mathrm{w}$ procesie „nadrukowania" ślimaka drutem ER 308 na rurę nierdzewną o średnicy $40 \mathrm{~mm}$. Podczas jego wykonywania połączono ruch obrotowy poziomo zamocowanej rury podkładowej z ruchem robota odtwarzającym kolejne zwoje ślimaka.

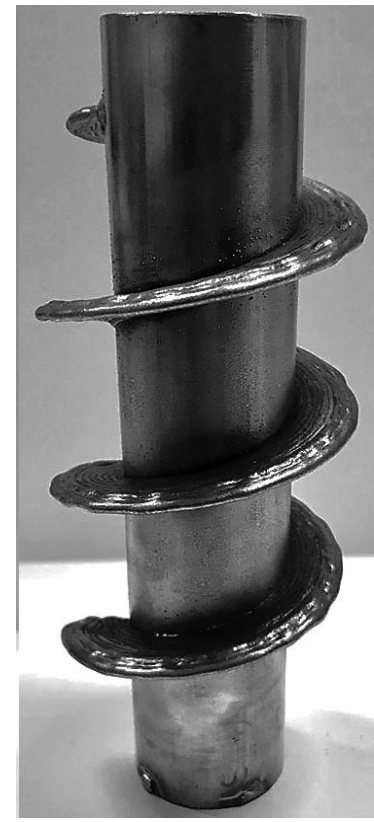

Rys. 5. Model podajnika ślimakowego napawanego na rurze stalowej Fig. 5. Model of a screw feeder welded on a steel pipe

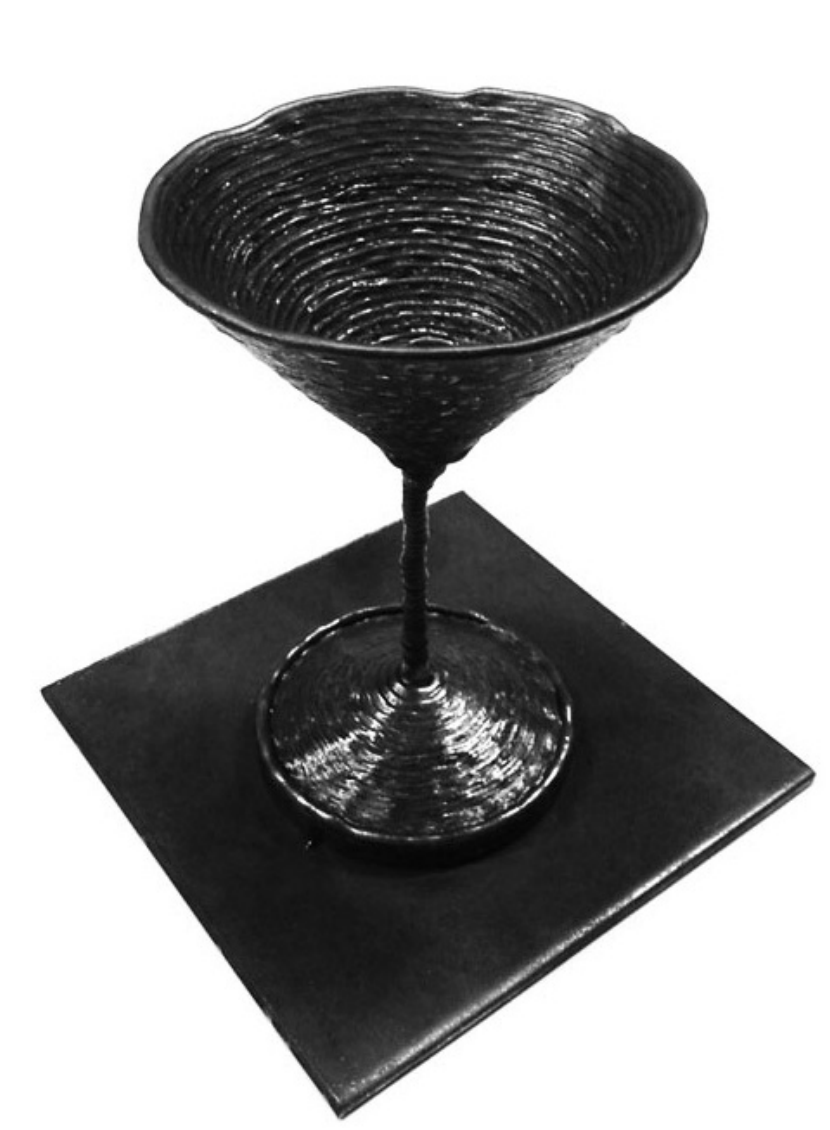

Dotychczasowe obserwacje makroskopowe zgładów metalograficznych "wydruków” wskazują na ich jednorodną strukturę. Widoczne są niewielkie i rzadko występujące porowatości. Powierzchnia zgładów jest wolna od pęknięć i pęcherzy podskórnych oraz jam skurczowych. Badania mikroskopowe obiektów ze stali konstrukcyjnej G3Si1 ujawniły pozytywny wpływ kolejno dobudowywanych warstw na już wytworzone - odpuszczanie naprężeń spawalniczych oraz rekrystalizację. Dopiero warstwy wytworzone jako ostatnie miały mikrostrukturę charakterystyczną dla spoin, natomiast pozostałe ferrytyczno-perlityczną [8]. Badania obiektów wytworzonych przy wykorzystaniu innych materiałów, w tym ze stali nierdzewnych, będą przedmiotem kolejnych publikacji.

\section{Perspektywy dalszych badań}

Wśród planowanych, nowych kierunków badań należy wskazać dalsze rozszerzanie palety materiałów, obejmujące oprócz wspomnianego ER 316LSi, drut ze stopu magnezu AZ31. Wobec braku odpowiedniej linii synergicznej w źródle TPS 2700 CMT konieczne będzie przeprowadzenie szeregu wstępnych prób i badań, a na ich podstawie modyfikacja parametrów w zakresie dostępnym za pośrednictwem sterownika RCU 5000i. Wcześniejsze próby spawania blach ze stopu AZ31 metodą CMT [11] wskazują na szereg problemów technologicznych, jakie mogą towarzyszyć również podczas prób drukowania 3D.

Po opanowaniu metod wytwarzania obiektów walcowych dalsze działania koncentrować się będą na obiektach prostopadłościennych. Dotychczasowe działania wskazują $\mathrm{m}$. in. na trudności w uzyskaniu prostoliniowego zarysu górnej krawędzi względem naroży (rys. 6) oraz niedostatecznej powtarzalności podczas kształtowania powierzchni skośnych.
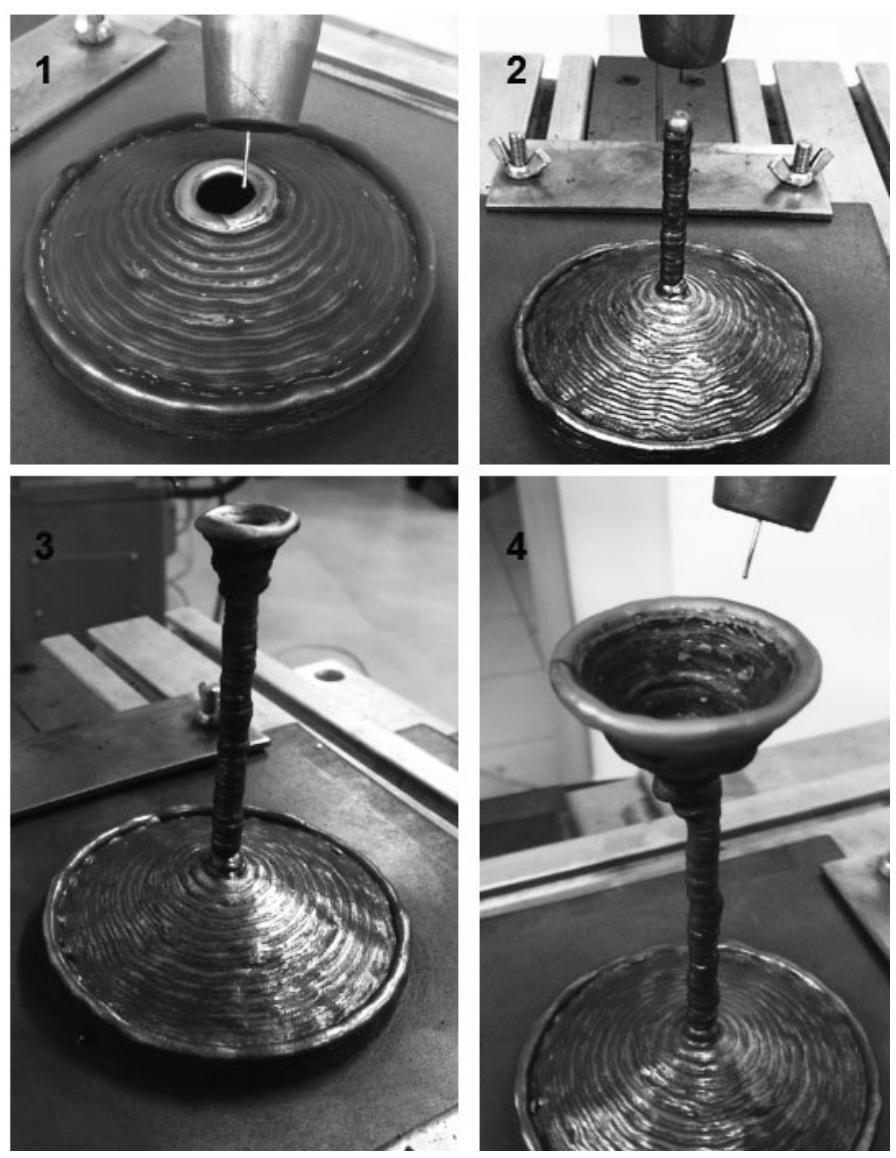

Rys. 4. Kieliszek o wysokości ok. $165 \mathrm{~mm}$ i średnicy zewn. $120 \mathrm{~mm}$ wytworzony z drutu G3Si1 (efekt końcowy oraz stadium budowy nóżki) Fig. 4. A glass with a height of approx. $165 \mathrm{~mm}$ and an external diameter of $120 \mathrm{~mm}$ made of G3Si1 wire (final effect and stage of foot construction) 


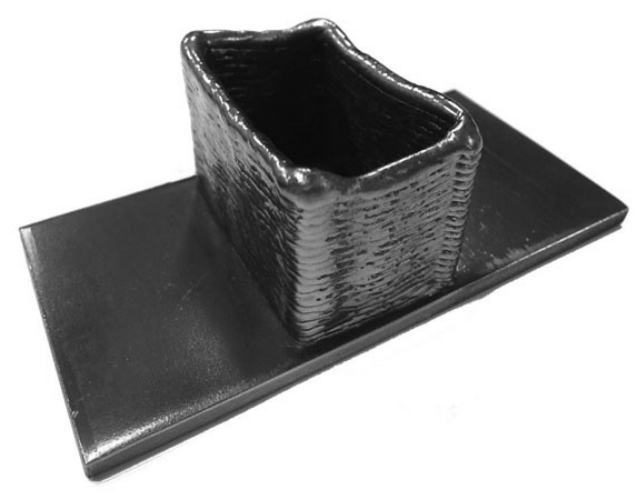

Rys. 6. Obiekt prostopadłościenny wytworzony w toku wczesnych eksperymentów

Fig. 6. A rectangular object created in the course of early experiments

W ramach indywidualnych projektów dyplomowych współautorów niniejszej publikacji prowadzone są szczegółowe badania właściwości użytkowych obiektów wytworzonych przy wykorzystaniu stali nierdzewnych (Mateusz Ostrysz) oraz próby określenia możliwości intensyfikacji procesu, m.in. w oparciu o kontrolowane chłodzenie międzywarstwowe (Wojciech Łacisz).

W trakcie pierwszej z prac, dzięki opanowaniu wytwarzania wysokich ścian możliwe stało się przygotowanie pełnowymiarowych próbek do badań, m.in. wytrzymałości na rozciąganie (rys. 7 i 8). Przeprowadzone testy wskazują na wysokie walory użytkowe wykonywanych obiektów. Szczegółowe wyniki będą przedmiotem kolejnej publikacji.

Dotychczasowe eksperymenty wskazują na konieczność okresowego przerywania procesu (zwykle po kilku warstwach) i odczekanie, aż tworzony obiekt schłodzi się do określonej eksperymentalnie temperatury. W przeciwnym wypadku obserwowano postępującą deformację nadmiernie nagrzewającego się modelu. Badania nad przyspieszeniem cyklu nakładania warstw wymagały zbudowania stanowiska z kontrolowanym schładzaniem pomiędzy warstwami poprzez nadmuch zimnego powietrza (o różnej intensywności) a)
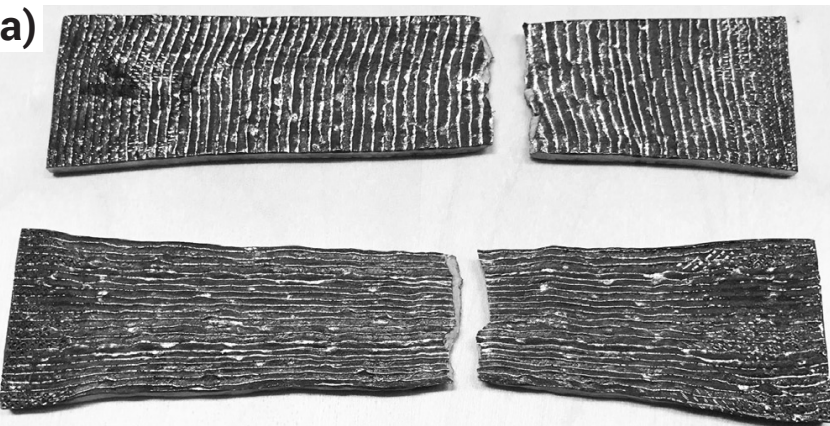

b)
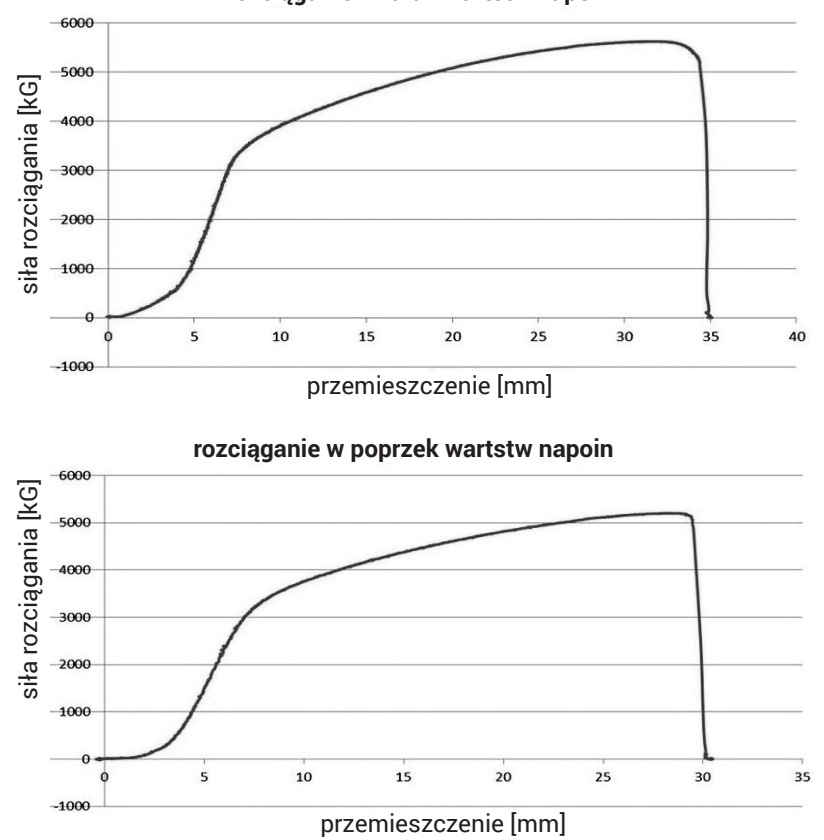

Rys. 8. Próbki podczas prób rozciągania: a) w poprzek warstw napoin, b) wzdłuż warstw

Fig. 8. Samples during tensile tests: a) across the padding layers, b) along the layers
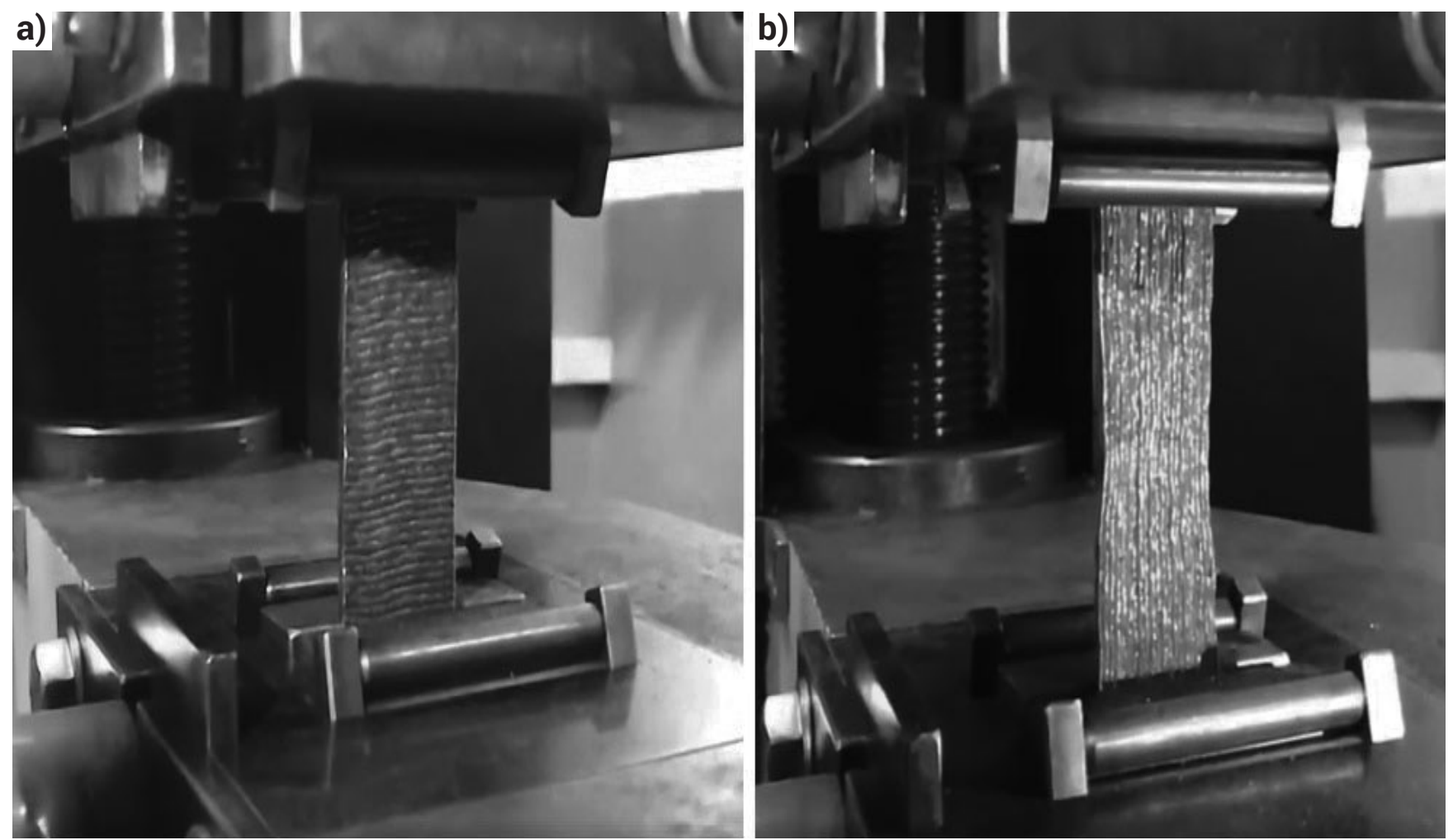

Rys. 7. Próbki podczas prób rozciągania: a) w poprzek warstw napoin, b) wzdłuż warstw Fig. 7. Samples during tensile tests: a) across the padding layers, b) along the layers 


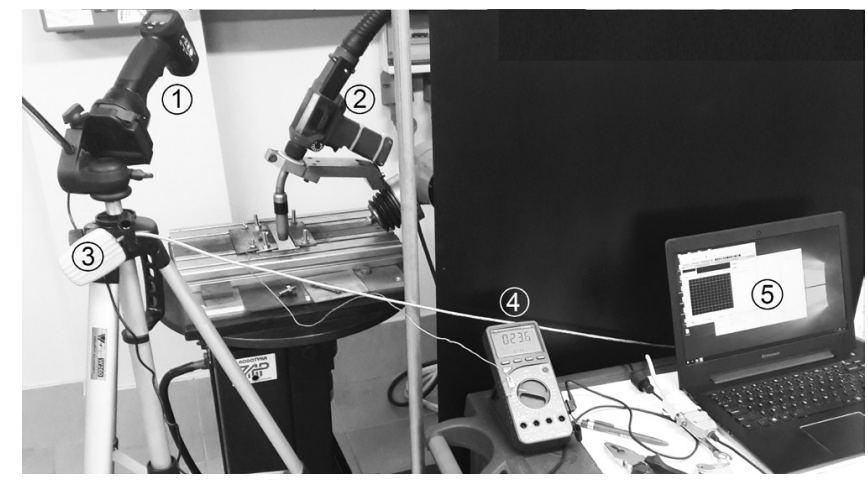

Rys. 9. Stanowisko podczas wielowarstwowego napawania z rejestracją temperatury: 1) pirometr, 2) uchwyt spawalniczy CMT, 3) przekaźnik do transmisji danych do komputera, 4) multimetr, 5) rejestracja komputerowa

Fig. 9. Stand during multi-layer welding with temperature recording: 1) pyrometer, 2) CMT welding holder, 3) relay for data transmission to a computer, 4) multimeter, 5) computer registration

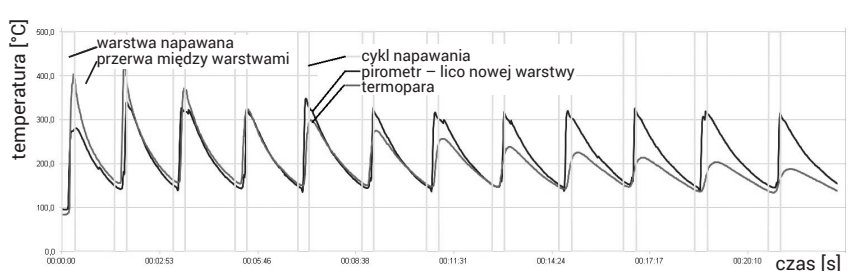

Rys. 10. Przykład rejestracji temperatury

Fig. 10. Example of temperature recording

i precyzyjną rejestracją cyklu termicznego (rys. 9 i 10). W tym celu wykorzystano m.in. pirometr z rejestracją komputerową oraz zintegrowany $z$ robotem system monitorowania parametrów procesu, tu wykorzystywany do rejestracji temperatury mierzonej z wykorzystaniem multimetru i termopary $\mathrm{K}$ (tabl. I). Jedną z najciekawszych obserwacji, wymagających dalszego zbadania, było widoczne zmniejszenie się chropowatości powierzchni zewnętrznej modeli wraz z wprowadzeniem dodatkowego schładzania międzywarstwowego nadmuchem zimnego powietrza. Szczegółowe wyniki badań będą przedmiotem kolejnej publikacji.

Tablica I. Przyrządy wykorzystywane do pomiaru i rejestracji temperatury

Table I. Instruments used to measure and record temperature

\begin{tabular}{|c|c|c|c|c|c|}
\hline Nazwa & Model & Zakres pomiarowy & Dokładność & $\begin{array}{c}\text { Rozdzielczość } \\
\text { pomiarowa }\end{array}$ & $\begin{array}{c}\text { Rozdzielczość } \\
\text { optyczna }\end{array}$ \\
\hline Pirometr & $\begin{array}{l}\text { Abatronic } \\
\text { AB-8855 }\end{array}$ & $-50 \div 1050^{\circ} \mathrm{C}$ & $\begin{array}{l}-50 \div 200{ }^{\circ} \mathrm{C} \pm 1,5 \% \\
200 \div 538{ }^{\circ} \mathrm{C} \pm 2,0 \% \\
538 \div 1050{ }^{\circ} \mathrm{C} \pm 3,5 \%\end{array}$ & $0,1^{\circ} \mathrm{C}$ & $30: 1$ \\
\hline & Metex M-4660A & $-40 \div 1200^{\circ} \mathrm{C}$ & $\pm 3,5 \%$ & $0,1^{\circ} \mathrm{C}$ & - \\
\hline z termoparą & Termopara typ $\mathrm{K}$ & $-40 \div 1200^{\circ} \mathrm{C}$ & $\begin{array}{c}-40 \div 333^{\circ} \mathrm{C} \pm 2,5 \% \\
333 \div 1200{ }^{\circ} \mathrm{C} \pm 0,0075 \times T \%\end{array}$ & \multicolumn{2}{|c|}{ czułość $41 \mu \mathrm{V} /{ }^{\circ} \mathrm{C}$} \\
\hline
\end{tabular}

\section{Podsumowanie}

Dzięki modelowaniu 3D można wytwarzać przedmioty o często bardzo złożonych kształtach, bez potrzeby stosowania specjalnego oprzyrządowania i narzędzi, których wykonanie innymi metodami może być kłopotliwe, drogie, a niekiedy nawet niemożliwe. Może to mieć szczególne zastosowanie np. podczas prototypowania nowych urządzeń, produkcji jednostkowej czy napraw bez dostępu do odpowiednich maszyn i materiałów.

Wytwarzanie addytywne (druk 3D) jest, obok robotyzacji, nowych materiałów oraz systemów zbierania i raportowania danych „w chmurze”, jednym z filarów tzw. inteligentnej fabryki (ang. smart factory), intensywnie rozwijanej w ramach nowej idei Przemysłu 4.0 [8].

Interesujący wydaje się rozwój tanich i wydajnych technik druku 3D elementów metalowych, konkurencyjnych zarówno dla tradycyjnych procesów wytwarzania, jak i znanych metod druku 3D, np. scalania wiązka lasera. Jednym z takich procesów może być omówione w artykule wielowarstwowe napawanie łukowe metodami MIG/MAG.

Przedstawione wyniki badań i eksperymentów wskazują na perspektywiczny charakter zrobotyzowanego napawania MIG/MAG w roli drukowania obiektów 3D. Oprócz niezaprzeczalnych zalet należy także poznać ograniczenia metody, zarówno w odniesieniu do możliwych do uzyskania kształtów, właściwości mechanicznych, jak i kosztów.

\section{Literatura}

[1] Klimpel A.: Napawanie i natryskiwanie cieplne, WNT Warszawa 2000.

[2] Kolasa A., Sarnowski T., Cegielski P.: Regeneration of Worn Out Machine Parts Surfaces by Aut. Welding, Przegląd Spawalnictwa 1/2015.

[3] Kolasa A.: Uszkodzenia i naprawy metalowych części maszyn, Wydawnictwa Politechniki Warszawskiej, Warszawa 1997.

[4] Siemiński P., Budzik G.: Techniki przyrostowe. Druk 3D. Drukarki 3D, Oficyna Wydawnicza Politechniki Warszawskiej, Warszawa 2015

[5] Uziel A.: Looking at Large-Scale, Arc-Based Additive Manufacturing, WeIding Journal 4/2016.

[6] Cegielski P.: Nowe obszary zastosowania napawania łukowego MIG/MAG, Przegląd Spawalnictwa 6/2016, s. 48-49.

[7] Cegielski P., Skublewska A., Gawroński P., Ostrysz M., Dylewski M., Gajowniczek M.: Zastosowanie napawania łukowego MIG/MAG do drukowania 3D, Spajanie 2/2016, s. 22-26.
[8] Cegielski P., Skublewska A., Gawroński P., Ostrysz M., Dylewski M., Gajowniczek M.: Zrobotyzowane drukowanie 3D części maszyn metodami spawalniczymi, Przegląd Spawalnictwa 1/2017, s. 35-42.

[9] Panas M., Kowalski P., Ostrysz M., Łacisz W., Cegielski P. i inni.: Zastosowanie zrobotyzowanego napawania łukowego w tworzeniu modeli technikami przyrostowymi, Biuletyn Instytutu Spawalnictwa w Gliwicach 6/2017, s. 59-62

[10] Ostrysz M., Cegielski P., Skublewska A., Gajowniczek M., Dylewski M., Gawroński P.: Additive 3D printing using MAG CMT arc surfacing, 9th international conference, National Academy of Sciences of Ukraine, 2017, s. 7-14.

[11] Kołodziejczak P., Cegielski P., Kolasa A. Spawanie blach ze stopu magnezu AZ31 metodą MIG w odmianie CMT, Przegląd Spawalnictwa 10/2015, s. $72-76$. 